\title{
MODIS snowline elevation changes during snowmelt runoff events in Europe
}

\author{
Juraj Parajka $^{1^{*}}$, Nejc Bezak ${ }^{2}$, John Burkhart ${ }^{3}$, Bjarki Hauksson ${ }^{3}$, Ladislav Holko ${ }^{4}$, Yeshewa Hundecha ${ }^{5}$, \\ Michal Jenicek ${ }^{6}$, Pavel Krajčí ${ }^{7}$, Walter Mangini ${ }^{1}$, Peter Molnar ${ }^{8}$, Philippe Riboust $^{9,10}$, Jonathan Rizzi ${ }^{11}$, \\ Aynur Sensoy $^{12}$, Guillaume Thirel ${ }^{9}$, Alberto Viglione ${ }^{1}$
}

1 Institute of Hydraulic Engineering and Water Resources Management, Vienna University of Technology, Vienna, Austria.

2 Faculty of Civil and Geodetic Engineering, University of Ljubljana, Ljubljana, Slovenia.

3 The Faculty of Mathematics and Natural Sciences, Department of Geosciences, University of Oslo, Oslo, Norway.

4 Institute of Hydrology, Slovak Academy of Sciences, Bratislava, Slovakia.

5 Swedish Meteorological and Hydrological Institute, Folkborgsvägen 17, 601 76, Norrköping, Sweden.

6 Department of Physical Geography and Geoecology, Charles University, Prague, Czech Republic.

7 Avalanche Prevention Centre, Mountain Rescue Service, Liptovsky Hradok, Slovakia.

8 Department of Civil, Environmental and Geomatic Engineering, Institute of Environmental Engineering, ETH Zurich, Zurich, Switzerland.

9 HYCAR Research Unit (HBAN), Irstea, 1 rue Pierre-Gilles de Gennes, CS 10030, 92761 Antony Cedex, France.

${ }^{10}$ Sorbonne Universités, UPMC Univ., Paris 06, CNRS, EPHE, UMR 7619 Metis, 4 place Jussieu, 75005 Paris, France.

${ }^{11}$ Division Forests and Forest Resources, Department Forest and Climate, Norwegian Institute of Bioeconomy Research, Ås, Norway.

${ }^{12}$ Department of Civil Engineering, Anadolu University, Eskisehir, Turkey.

${ }^{*}$ Corresponding author. E-mail: parajka@hydro.tuwien.ac.at

\begin{abstract}
This study evaluates MODIS snow cover characteristics for large number of snowmelt runoff events in 145 catchments from 9 countries in Europe. The analysis is based on open discharge daily time series from the Global Runoff Data Center database and daily MODIS snow cover data. Runoff events are identified by a base flow separation approach. The MODIS snow cover characteristics are derived from Terra $500 \mathrm{~m}$ observations (MOD10A1 dataset, V005) in the period 2000-2015 and include snow cover area, cloud coverage, regional snowline elevation (RSLE) and its changes during the snowmelt runoff events. The snowmelt events are identified by using estimated RSLE changes during a runoff event. The results indicate that in the majority of catchments there are between 3 and 6 snowmelt runoff events per year. The mean duration between the start and peak of snowmelt runoff events is about 3 days and the proportion of snowmelt events in all runoff events tends to increase with the maximum elevation of catchments. Clouds limit the estimation of snow cover area and RSLE, particularly for dates of runoff peaks. In most of the catchments, the median of cloud coverage during runoff peaks is larger than $80 \%$. The mean minimum RSLE, which represents the conditions at the beginning of snowmelt events, is situated approximately at the mean catchment elevation. It means that snowmelt events do not start only during maximum snow cover conditions, but also after this maximum. The mean RSLE during snowmelt peaks is on average $170 \mathrm{~m}$ lower than at the start of the snowmelt events, but there is a large regional variability.
\end{abstract}

Keywords: MODIS; Snowmelt; Runoff events; Europe; Snowline elevation.

\section{INTRODUCTION}

Snow cover distribution in alpine catchments plays a key role in runoff generation during spring melt season. Snowcovered and snow-free parts of the catchments respond differently to rain and melt situations, which affects the timing and intensity of snowmelt runoff generation. Snow-free areas produce more rapid runoff response during rainfall events in winter and spring and the thermal conditions of the snow pack determine the amount of rain and melt which percolates into the snowpack and hence delays or retains the transit of water contributing to runoff (Collins, 1998).

Satellite images of snow cover, such as from MODIS (Hall and Riggs, 2016) enable an effective and accurate way to determine the snow covered areas over large regions (Parajka and Blöschl, 2012). Previous studies demonstrated that MODIS snow cover maps can be used for mapping of catchment snow cover area (e.g. Paudel and Andersen, 2011; Wang et al., 2009; Xinghua et al., 2017), seasonal snow cover duration (Dietz et al., 2012; Gascoin et al., 2015; Wang et al., 2015) or snow cover depletion (Déry et al., 2005; Li et al., 2008; Riboust et al., 2019). A recent study of Krajčí et al. (2014) proposed and evaluated a method to describe the snow cover distribution in catchments by a time varying snow line elevation. The results indicate that spatial patterns of snow cover during snowmelt period closely follow topography and snow line elevation approach can be used to describe snow cover distribution in alpine basins.

Most of the previous studies analysed and evaluated MODIS snow cover products at seasonal or monthly time scale. The main objective of this study is to analyse snow cover characteristics derived from MODIS datasets for individual snowmelt runoff events in a large number of European catchments. The specific research questions are:

What are the MODIS-derived snow characteristics (i.e. snow cover area, cloud coverage, snow line elevation) during snowmelt runoff events?

How does the snowline elevation change during snowmelt runoff events?

What are the spatial and temporal differences in snowline elevation across Europe during snowmelt runoff events?

This study goes beyond the existing literature in that it investigates the spatial variability of snow cover and its changes during snowmelt runoff events. The main interest is to analyse snow cover changes using the variability in snowline elevation in the time period between the beginning and the peak of the 
runoff events. Assessment of the variability in a large number of catchments and runoff events allows a robust comparative assessment of spatial and temporal patterns of snow cover changes during snowmelt periods across Europe.

The context of the study is determined by the setup of experiments in the Virtual Water Science Laboratory developed within the EU SWITCH-ON project (http://www.water-switchon.eu/). One of the main scientific aims of the project is to develop new forms of research in support of open science (Ceola et al., 2015). The Virtual Water Science Laboratory provides a platform to support reproducibility and transparency of hydrological analyses and experiments. This study is one of the test cases, evaluating not only the aspect of regional snow line elevation changes during snowmelt runoff events, but also testing the platform for research collaboration between external partners. The Virtual Water Science Laboratory provides open access to all input and output data, as well as to computational tools used in the analysis, so it allows to fully reproduce the methodology applied in the study (protocol to experiment is available here: http://dl-ng005.xtr.deltares.nl/view/40/). On the contrary, the requirement of open science and open call for the collaboration has an impact on the number and location of analysed catchments and the methodological setup of the experiment.

\section{METHODS}

The methodology applied for the analysis of MODIS snow line elevation changes during snowmelt runoff events consists of three steps. In the first step, all runoff events are identified from daily discharge time series and the starting date and date of runoff peak are determined. In the second step, the regional snow line elevation (RSLE) is estimated from daily MODIS images for selected catchments. The RSLE is identified for all days without significant cloud coverage (i.e. less than $80 \%$ ). If during the runoff events (i.e. between the start and the peak) a change in RSLE (i.e. decrease in snow cover area) occurs then those events are classified and selected as driven by snowmelt. In the third step, the MODIS and RSLE characteristics and their changes during the selected snowmelt events are evaluated. The following three sections provide a detailed description of the applied methodology.

\section{Identification of runoff events}

The methodology used for the identification of runoff events and corresponding peaks is based on a base flow separation approach. Base flow separation is used to identify the points in time at which the runoff event starts and ends. While the starting point refers to a point when the flow starts to increase, the end-point refers to a time when the plot of logarithmic transformed discharge values against time becomes a straight line. For the establishment of the end-points, a wide range of techniques is available. In this study, we apply the Chapman digital filter (Chapman, 1999), which estimates the base flow as a simple weighted average of the base flow at the previous time interval and the direct runoff at given time interval, i.e.

$Q_{b}(i)=k Q_{b}(i-1)+(1-k) Q_{d}(i)$

where $Q_{b}(i)$ and $Q_{d}(i)$ are the daily base flow and direct runoff at time interval $i$, respectively. The parameter $k$ is the flow recession constant, which is in this study estimated by the approach of Vogel and Kroll (1996) (see also Thomas et al.,
2013). More details about the steps used for estimation of the recession constant can be found in Mangini et al. (2018).

Once the recession constant is estimated, time-series of $Q_{b}(i)$ and $Q_{d}(i)$ are computed and independent runoff events are identified. The runoff peaks then represent the maximum daily discharge within each independent event, if the direct runoff is greater than both the base flow and mean annual direct runoff. This criterion is introduced to eliminate cases where discharge or base flow equals zero. All steps used for event identification are documented in an R-script, which is available at https://gist.github.com/duropa/c2590ad84f730e38b0b6c408ab4f a95a.

\section{Estimation of regional snow line elevation}

The regional snow line elevation (RSLE) is estimated by the methodology developed in Krajčí et al. (2014). It is based on processing satellite images of snow cover. The approach finds the elevation for which the sum of snow covered pixels below and land pixels above the RSLE is minimized for each time step (day). The approach is applied only for days when catchment cloud coverage is less than user defined threshold values. The threshold value of $80 \%$ was set in this study, based on the sensitivity analysis performed in Krajčí et al. (2014). For days with cloud coverage larger than $80 \%$, the RSLE was linearly interpolated from the nearest RSLE estimates. An illustrative example of estimated RSLE is presented in Figure 1.

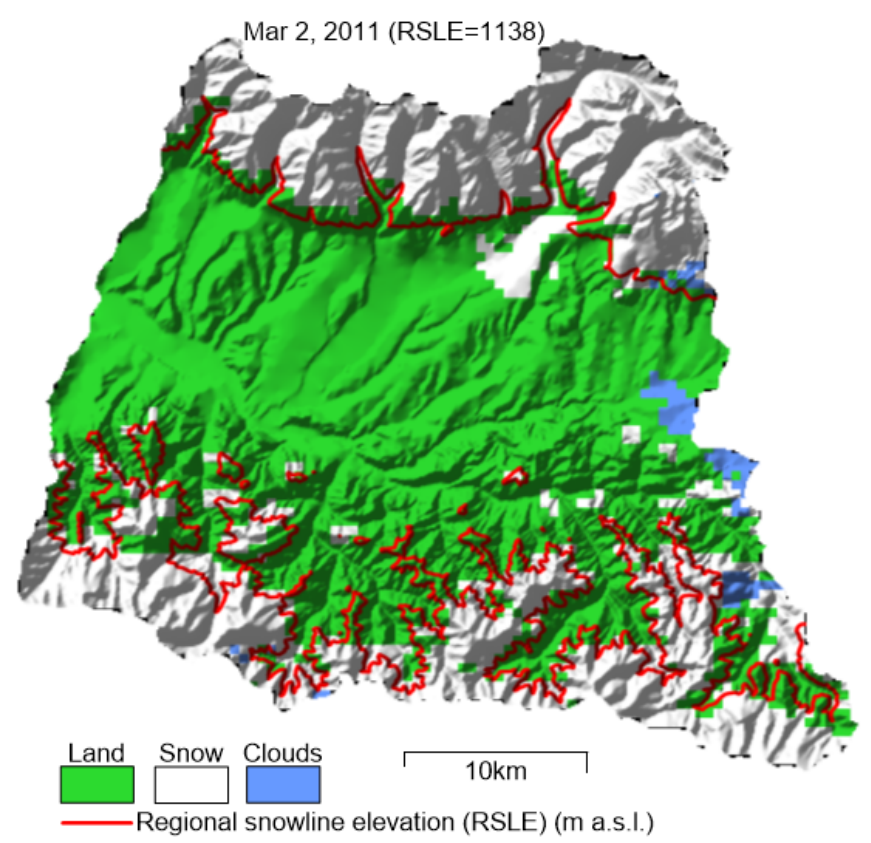

Fig. 1. Regional snowline elevation (RSLE, red line) estimated from MODIS snow cover data for the Upper Vah basin (Slovakia).

An R-script has been written to estimate the RSLE according to Krajčí et al. (2014) using MODIS daily images as a data source. The code is available at: https://gist.github.com/duropa/596a1ad28d14547bfdd3f1f22f75 ccb5. The script includes the commands used for processing and reprojection of MODIS images, digital elevation model and catchment boundary. The outputs are time series of RSLE, and the frequencies of pixels classified in MODIS as snow covered, land and clouds. 


\section{Estimation of changes in RSLE during snowmelt events}

The estimation of changes in RSLE (results presented in sub-section "Change in regional snowline elevation during snowmelt events") is schematically demonstrated in Figure 2. The dotted line shows daily discharge time series for the Lech catchment in Austria. The yellow background outlines the duration of the identified snowmelt event. In the analysis, the changes in RSLE are evaluated between the start and the peak of an event. The changes in RSLE are presented as a blue line with blue triangle symbols indicating the relative amount of cloud covered pixels in the catchment. Two types of RSLE changes are assessed. The first (RSLE1) indicates the maximum change in snowline elevation during an event. The second change (RSLE2) shows the difference between the first and last day of RSLE changes during an event. In case of significant cloud coverage (i.e. clouds $>80 \%$ ) the RSLE2 change is estimated to the days closest to the first or last day of RSLE change within an identified event. The duration of an event is in this study defined as the number of days between the beginning of event and the snowmelt peak. If the event is not accompanied by a change in RSLE it is not considered a snowmelt event.

\section{DATA}

The analysis of snowline elevation changes is performed in 145 catchments in 9 countries of Europe. Table 1 lists the number of catchments in each country and the range of their size and gauge elevation. The median of catchment size and gauge elevation is $265.6 \mathrm{~km}^{2}$ and $523 \mathrm{~m}$ a.s.1., respectively. The location of the catchments is presented in Figure 3.

The selection of catchments is determined by the availability of daily discharge and MODIS snow cover data, by the significance of anthropogenic influence, and by the climate region indicating where snowmelt is one of the important flood generation processes. The core for the selection is the open dataset of the pan-European catalogue of flood events (Parajka, 2017), which lists runoff events identified for 1315 gauging stations available in the Global Runoff Data Centre (GRDC) database (http://www.bafg.de/GRDC/EN/Home/homepage_node.html).

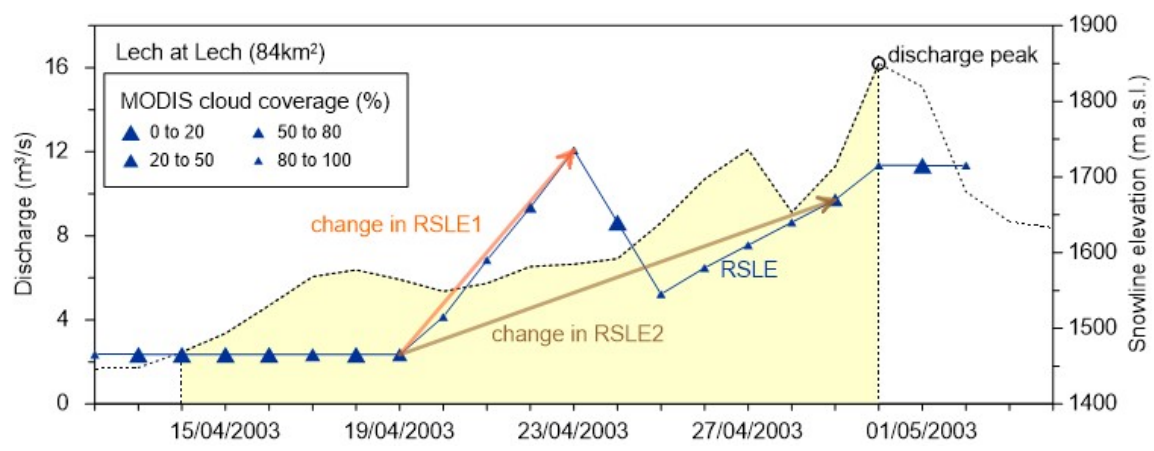

Fig. 2. An example of changes in regional snowline elevation from MODIS (RSLE, blue line) during a snowmelt event (dotted line, filled by yellow). Size of blue symbols indicates the cloud coverage. Two arrows indicate two types of RSLE changes. The first type is determined by the largest difference in RSLE during an event (RSLE1), the second type indicates the change in RSLE (RSLE2) between the start and end of an event (if cloud coverage is less $80 \%$ ).

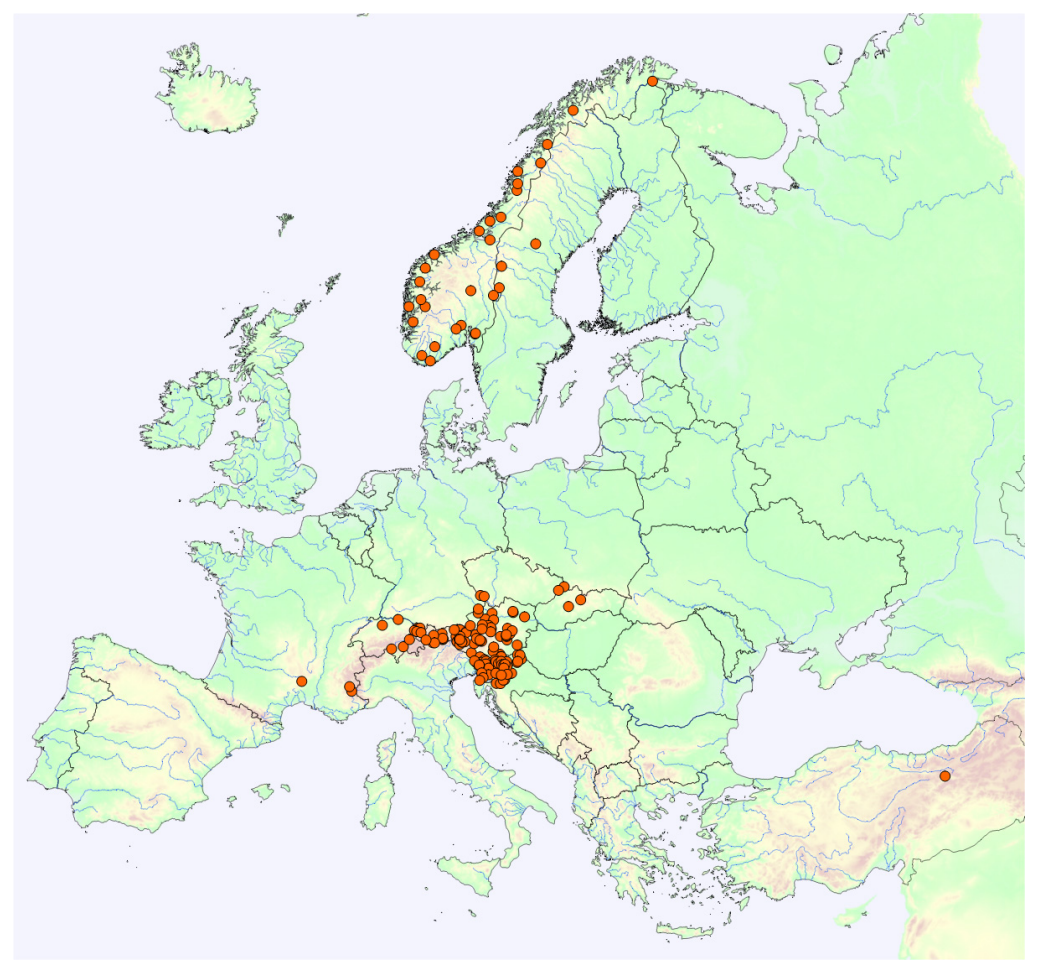

Fig. 3. Location of gauging stations (circles) selected for analysis of regional snow line elevation changes in Europe. 
Table 1. Summary of catchments used for analysis of regional snowline elevation and their basic characteristics.

\begin{tabular}{|l|l|l|l|l|}
\hline Country & $\begin{array}{l}\text { Number of } \\
\text { catchments }\end{array}$ & $\begin{array}{l}\text { Total number of analysed } \\
\text { snowmelt events }\end{array}$ & $\begin{array}{l}\text { Min-median-max of gauge } \\
\text { elevation }(\mathrm{m} \text { a.s.1.) }\end{array}$ & $\begin{array}{l}\text { Min-median-max of mean } \\
\text { catchment area }\left(\mathrm{km}{ }^{2}\right)\end{array}$ \\
\hline Austria & 48 & 1555 & $230-730-2000$ & $10-149-25600$ \\
\hline Czech Republic & 4 & 159 & $520-*-970$ & $14-*-176$ \\
\hline France & 3 & 100 & $840-*-1160$ & $70-*-2170$ \\
\hline Norway & 27 & 1596 & $155-654-1224$ & $16-491-40540$ \\
\hline Slovakia & 2 & 95 & $330-*-570$ & $1100-*-1800$ \\
\hline Slovenia & 52 & 3254 & $60-265-800$ & $40-294-14600$ \\
\hline Switzerland & 5 & 351 & $350-620-1580$ & $24-260-10150$ \\
\hline Sweden & 3 & 135 & $279-*-579$ & $340-*-2430$ \\
\hline Turkey & 1 & 61 & 1140 & 10270 \\
\hline
\end{tabular}

*not enough values to estimate median

Additionally, daily discharge data from Slovenia, Czech Republic and Turkey have been processed using the same approach as applied in the Catalogue of flood peaks. Finally, stations with at least 6 years of daily discharge observations in the period 2000-2015 have been selected. The median data record length of these stations is 12 years and the total number of analysed snowmelt events is presented in Table 1.

Regional snow line elevation is processed from daily MODIS snow cover data (MOD10A1, version 005, spatial resolution $500 \mathrm{~m}$ ) in the period 2000-2015. For each catchment, the corresponding MODIS tile is selected and data are downloaded, processed and re-projected to the national projection of each country. The RSLE is estimated from the SRTM 90m Digital Elevation Model (v 4.1, (http://srtm.csi.cgiar.org) downsampled to a spatial resolution of $500 \mathrm{~m}$.

\section{RESULTS}

\section{Characteristics of snowmelt events}

The mean number of identified snowmelt events in different countries is presented in Figure 4. On average, there are 5.6 snowmelt events per year in the selected catchments and time period. More than eight events per year are observed in most of the catchments in Norway and only a few alpine catchments in Austria, Slovenia and Switzerland. The proportion of snowmelt to all identified events (Figure 5) indicates that the proportion increases with increasing maximum elevation of the catchments. This relationship is the strongest in Austria, where the proportion of snowmelt events increases about $16 \%$ (ratio 0.16 ) per $1000 \mathrm{~m}\left(\mathrm{R}^{2}\right.$ of linear fit is 0.7$)$. Two low elevation catchments in Sweden make an exception, where snowmelt events represent about $80 \%$ of all identified events at Idre and Fyras stations. The proportion of snowmelt events increases also with increasing size of the catchments, particularly for catchments in Slovenia $\left(R^{2}=0.6\right)$ and Norway $\left(R^{2}=0.50\right)$. A comparison of larger datasets from Austria and Slovenia shows that the proportion of snowmelt events to all runoff events is generally smaller in Slovenia, but it depends mainly on the maximum elevation of the catchments. While for high altitude catchments with maximum elevation above $2600 \mathrm{~m}$ the proportion of snowmelt events is greater than $50 \%$ in both countries, for most of the catchments with maximum elevation below $1000 \mathrm{~m}$ the proportion of snowmelt events is less than $15 \%$ and $25 \%$ in Slovenia and Austria, respectively. It should be noted, however, that Slovenian dataset includes catchments situated in subMediterranean climate and also two transboundary catchments (Drau, Mura).

The mean duration of the identified snowmelt events (i.e. from start to peak) is 3.3 days (Figure 6). This is shorter than the mean length of all no snow events ( 8.5 days). While the

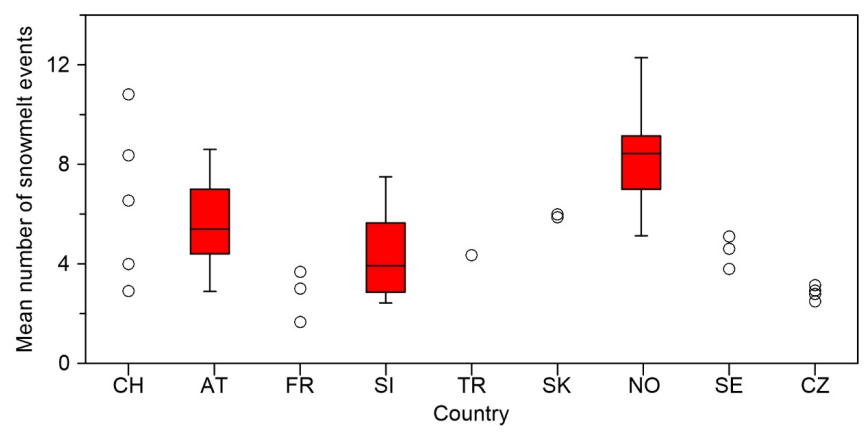

Fig. 4. Mean number of snowmelt events (per year) in selected catchments situated in Switzerland $(\mathrm{CH})$, Austria (AT), France (FR), Slovenia (SI), Turkey (TR), Slovakia (SK), Norway (NO), Sweden (SE) and Czech Republic (CZ) in the period 2000-2015. Box and whiskers for SI, AT and NO show $10^{\text {th }}-25^{\text {th }}-, 50^{\text {th }}$-, $75^{\text {th }}$ - and $90^{\text {th }}$-percentile values.

mean duration for the snowmelt events is the shortest in Slovenian catchments (median of mean length is 2 days), mean durations above seven days are found in two catchments in Sweden, France and Austria, Karasu catchment in Turkey and five catchments in Norway. In France, the mean duration of snow events seems to be longer due to the larger size of catchments. Interestingly, there is no clear statistical relationship between the mean duration of snowmelt events and the elevation characteristics or size of the catchments. This shows that runoff response to snowmelt is more affected by other characteristics, probably snow depth, structure and the amount of water stored in the snow at the beginning of the snowmelt, catchment area covered by vegetation, vegetation characteristics, weather conditions, etc.

The evaluation of the extent of snow cover area from MODIS (SCA) during snowmelt events is presented in Figure 7. The mean maximum SCA is plotted by the dotted lines. They indicate an average of maximum SCA during all snowmelt events identified in individual catchments. For comparison, the bold lines show the mean SCA estimated only for dates of snowmelt peaks. The results show that median of mean maximum SCA varies between $46 \%$ (Slovenian catchments) to $72 \%$ (Czech catchments). The median of mean SCA during snowmelt peaks is on average $10 \%$ smaller. The variability in SCA reflects the climatic differences among the countries. For example, while the mean SCA during snowmelt peaks in the Karasu catchment (Turkey) is less than $30 \%$, in the Norwegian catchments it exceeds $64 \%$. This likely corresponds to the difference in altitudinal distribution of snow cover in warmer and colder climates. The average change in SCA between beginning of event and runoff peak is the largest in catchments in 


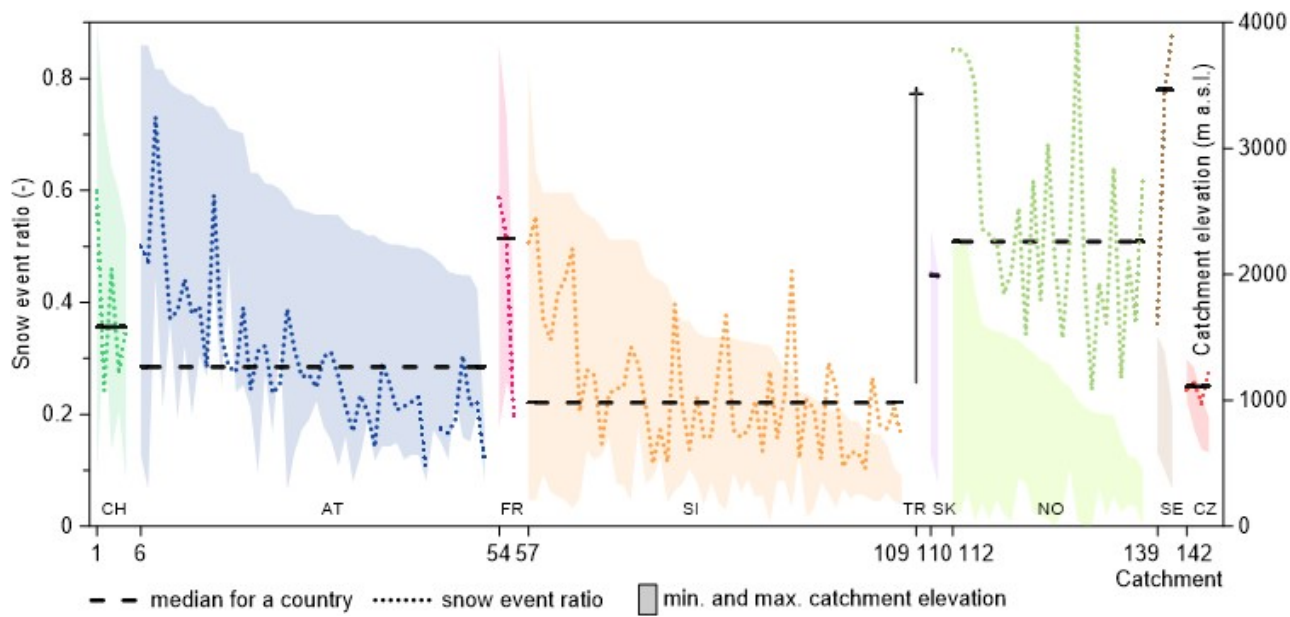

Fig. 5. Ratio of the number of snowmelt to all identified runoff events in selected catchments in Switzerland (CH), Austria (AT), France (FR), Slovenia (SI), Turkey (TR), Slovakia (SK), Norway (NO), Sweden (SE) and Czech Republic (CZ). Background colours show the elevation range in each catchment. Catchments are sorted according to countries and maximum catchment elevation. Dashed lines show the median values for individual countries.

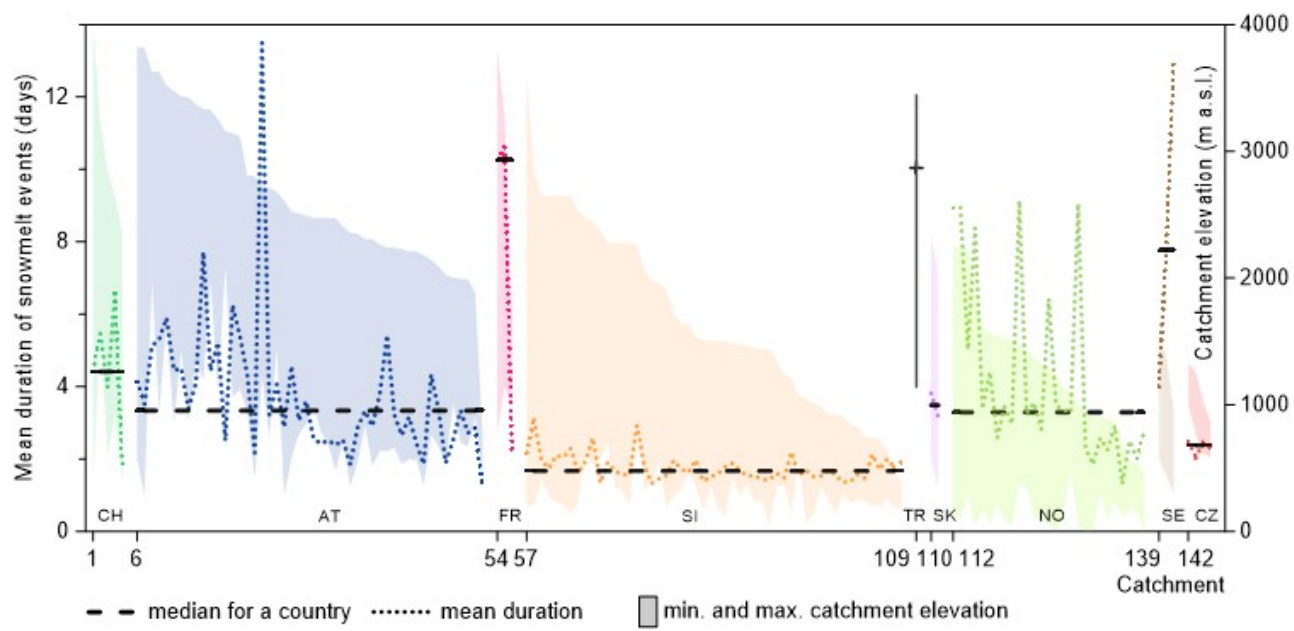

Fig. 6. Mean duration of snowmelt events (days from start to peak) in selected catchments in Switzerland (CH), Austria (AT), France (FR), Slovenia (SI), Turkey (TR), Slovakia (SK), Norway (NO), Sweden (SE) and Czech Republic (CZ). Background colours show the elevation range in each catchment. Catchments are sorted according to countries and maximum catchment elevation. Dashed lines show the median values for individual countries.

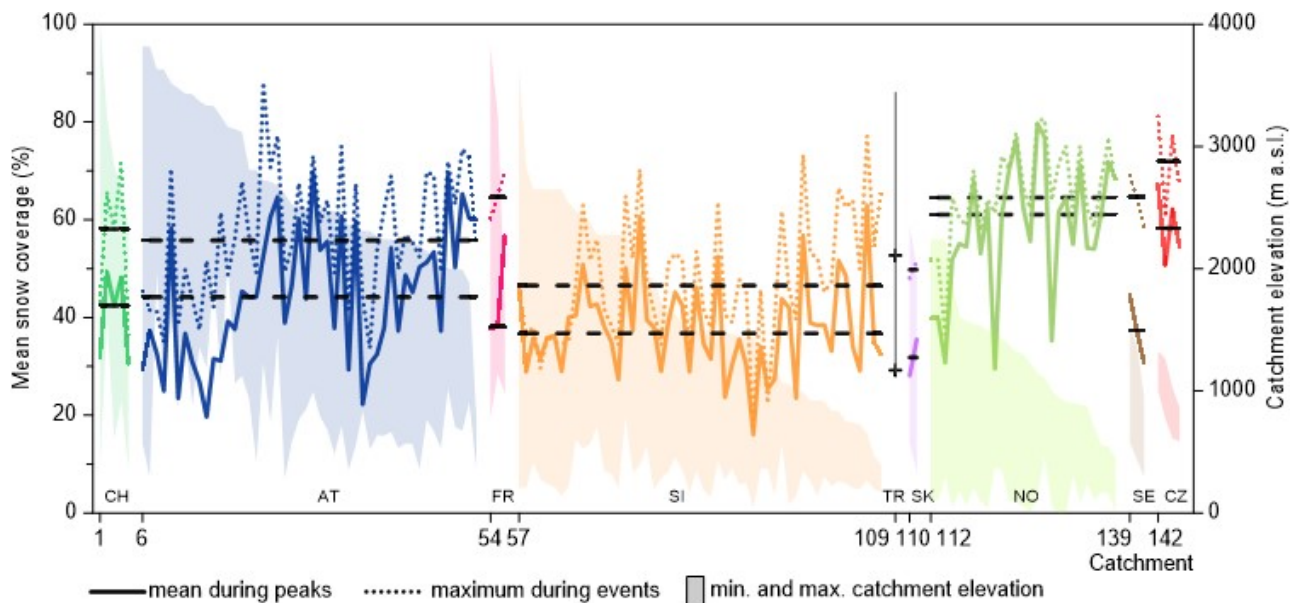

Fig. 7. Mean maximum snow cover area (SCA, dotted lines) during snowmelt events and mean SCA (bold lines) during runoff peaks estimated from MODIS images for 145 catchments in Europe in the period 2000-2015. Background colours show the elevation range in each catchment. Catchments are sorted according to countries and maximum catchment elevation. Dashed lines show the median snow coverage for individual countries. Catchments in different countries are plotted by different colours: Switzerland (CH), Austria (AT), France (FR), Slovenia (SI), Turkey (TR), Slovakia (SK), Norway(NO), Sweden (SE) and Czech Republic (CZ). The SCA is estimated from MODIS images if cloud coverage is less $80 \%$. 
Sweden and France (about 30\%). In Austria, Switzerland, Czech Republic and Slovakia it is between 17-20\% and the smallest difference is observed in Slovenian and Norwegian catchments (14\%). Interestingly, the average maximum SCA during snowmelt events tends to be smaller in catchments with higher maximum elevation than in lower elevation catchments. For example in Austria, the mean maximum SCA is 50\% in catchments with maximum elevation above $3000 \mathrm{~m}$, but about $70 \%$ in catchments with maximum elevation between 1000 and $2000 \mathrm{~m}$. In Slovenia, the mean maximum SCA is $40 \%$ and $60 \%$ in catchments with maximum elevation above $2500 \mathrm{~m}$ and below $1000 \mathrm{~m}$, respectively.

The estimation of SCA from MODIS is limited by the existence of cloud coverage. Figure 8 shows the mean catchment cloud coverage during snowmelt events (dotted lines) and runoff peaks (bold lines), respectively. It is clear that the cloud coverage during runoff peaks is large and the median of cloud coverage exceeds $80 \%$ in Austrian, Slovenian, Slovak and Czech catchments. The median of average cloud coverage during snowmelt events is however lower, which allows more robust estimation of snow cover characteristics from MODIS data. The largest difference between the medians of mean event and peak cloud coverage is in Czech (43\%) and Austrian (33\%) catchments. On the contrary in three catchments in Sweden, the difference is less than $5 \%(66 \%$ and $70 \%$ of clouds during event and peaks, respectively).

\section{Change in regional snowline elevation during snowmelt events}

The mean minimum regional snow line elevation for selected catchments is presented in Figure 9 (dotted lines). The minimum RSLE represents the conditions at the beginning of snowmelt events, when snow covers also the lower parts of the catchments. It is clear that the mean minimum RSLE is situated approximately in the middle between minimum and maximum elevation of the catchments, so the snowmelt events tend to start not only during maximum snow coverage of the catchments. The mean RSLE during snowmelt peaks (Figure 9, bold lines) is on average $170 \mathrm{~m}$ higher than at the start of the

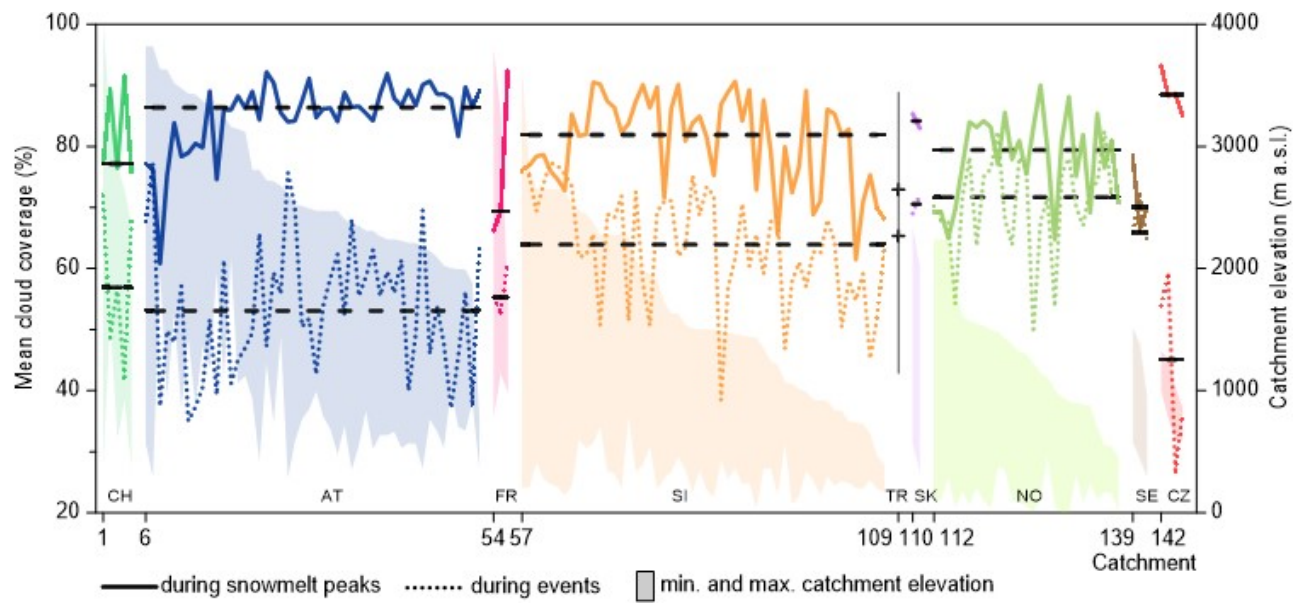

Fig. 8. The mean cloud coverage during snowmelt events and during snowmelt peaks for 145 catchments in Europe in the period 2000-2015. Background colours show the elevation range in each catchment. Catchments are sorted according to countries and maximum catchment elevation. Dashed lines show the median cloud coverage for individual countries. Catchments in different countries are plotted by different colours: Switzerland (CH), Austria (AT), France (FR), Slovenia (SI), Turkey (TR), Slovakia (SK), Norway (NO), Sweden (SE) and Czech Republic (CZ).

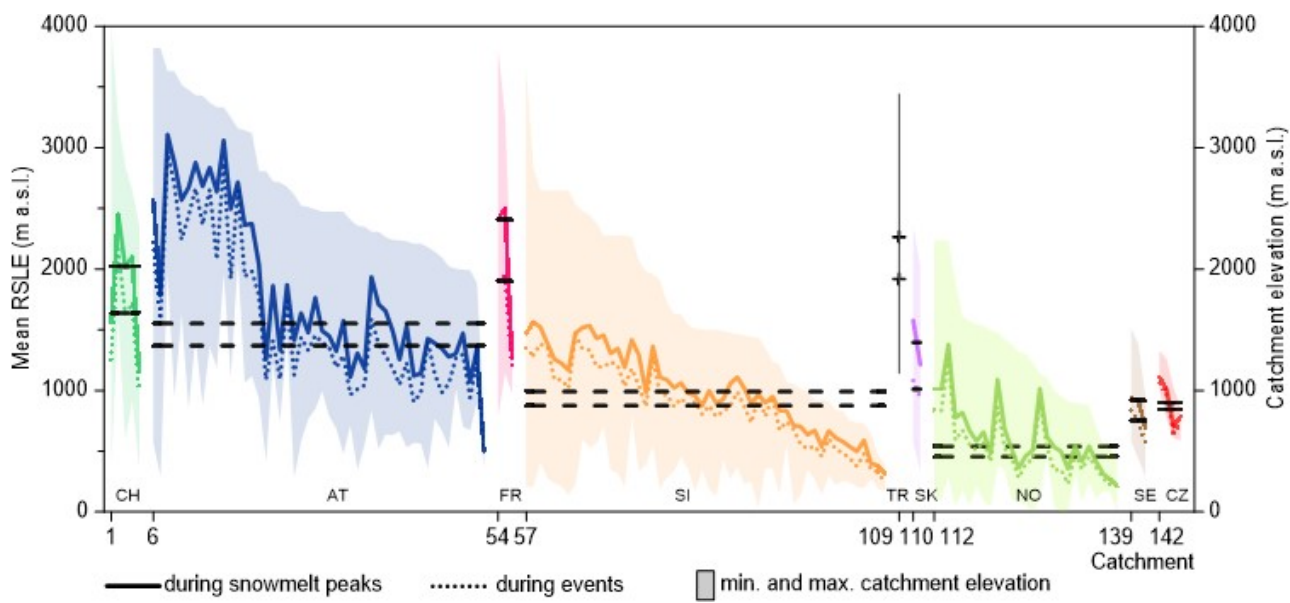

Fig. 9. Mean minimum regional snow line elevation (RSLE) during snowmelt events (dotted lines) and the mean RSLE during snowmelt peaks (bold lines) estimated from MODIS images for 145 catchments in Europe in the period 2000-2015. Background colours show the elevation range in each catchment. Catchments are sorted according to countries and maximum catchment elevation. Dashed lines show the median of mean RSLE for individual countries. Catchments in different countries are plotted by different colours: Switzerland (CH), Austria (AT), France (FR), Slovenia (SI), Turkey (TR), Slovakia (SK), Norway (NO), Sweden (SE) and Czech Republic (CZ). The RSLE is estimated from MODIS images if cloud coverage is less $80 \%$. 


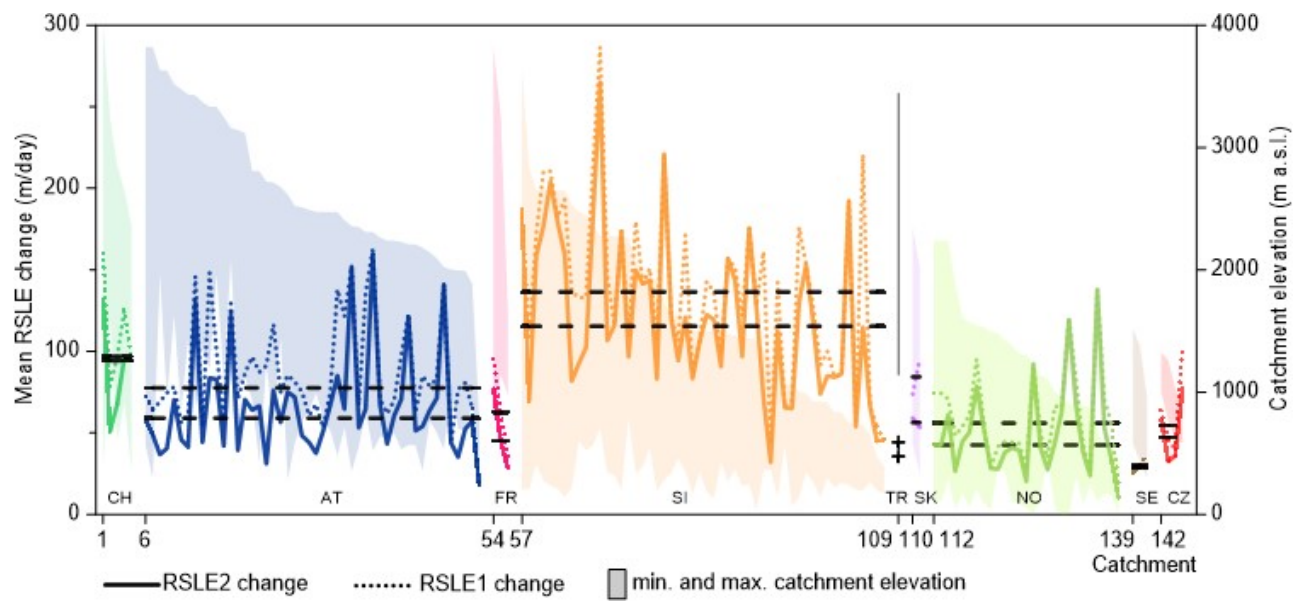

Fig. 10. Change in regional snow line (m/day) estimated by two different approaches (RSLE1, RSLE2, Sub-section "Estimation of changes in RSLE during snowmelt events") in selected 145 catchments in Europe. Background colours show the elevation range in each catchment. Catchments are sorted according to countries and maximum catchment elevation. Dashed lines show the median of mean RSLE change for individual countries. Catchments in different countries are plotted by different colours: Switzerland (CH), Austria (AT), France (FR), Slovenia (SI), Turkey (TR), Slovakia (SK), Norway (NO), Sweden (SE) and Czech Republic (CZ). The RSLE is estimated from MODIS images if cloud coverage is less $80 \%$.

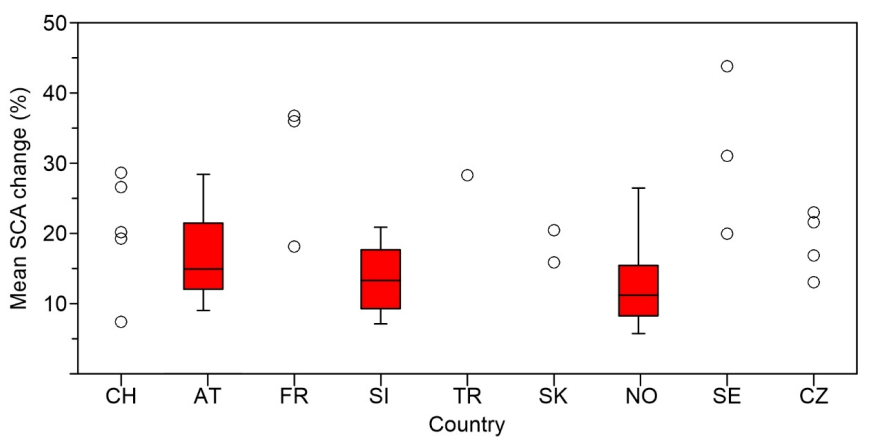

Fig. 11. Mean relative change in snow cover area (SCA) between the start and the peak of snowmelt events in selected catchments situated in in Switzerland (CH), Austria (AT), France (FR), Slovenia (SI), Turkey (TR), Slovakia (SK), Norway(NO), Sweden (SE) and Czech Republic (CZ) in the period 2000-2015. Box and whiskers for SI, AT and NO show $10^{\text {th }}-, 25^{\text {th }}-, 50^{\text {th }}-, 75^{\text {th }}-$ and $90^{\text {th }}-$ percentile values.

snowmelt events. While this difference is the largest in French (in two catchments larger than $500 \mathrm{~m}$ ) and Swiss (average difference $307 \mathrm{~m}$ ) catchments, the smallest differences are observed in four Czech catchments (average difference $51 \mathrm{~m}$ ). In Austria, catchments with maximum elevation above $3000 \mathrm{~m}$ have the mean minimum RSLE above $2300 \mathrm{~m}$ a.s.l., but the catchments with maximum elevation below $2500 \mathrm{~m}$ have the mean minimum RSLE below $1170 \mathrm{~m}$ a.s.l. In Slovenia, median of mean minimum RSLE is only $810 \mathrm{~m}$ a.s.l.

The evaluation of the change in RSLE between the start and peak of snowmelt events is presented in Figure 10. Comparison of the RSLE change obtained by the two different approaches (RSLE1, RSLE2, please see sub-section "Estimation of changes in RSLE during snowmelt events" for their difference) indicates very similar results. The mean absolute difference between the approaches is for all analysed catchments approximately $16 \mathrm{~m} /$ day. The absolute difference is larger than $50 \mathrm{~m} /$ day only in 5 Austrian and 4 Slovenian catchments. The mean change of RSLE, however varies for different countries. The largest change is observed in Slovenian catchments. The medians for the two approaches are 115 (RSLE2) and 136 (RSLE1) m/day. This is likely caused by generally warmer climate which leads to a faster melting phase. In catchments situated in lower latitudes, the shorter duration of snowmelt events causes the largest differences in RSLE. The scatter around the median is the largest in Slovenian catchments. The percentile difference (P75\%-P25\%) is $70 \mathrm{~m} /$ day for both approaches. In Austria, the medians and scatters of RSLE change are 59-77 m/day and $28-34 \mathrm{~m} /$ day, respectively. The smallest change is observed in three Swedish catchments, where the RSLE change varies between 25 and $36 \mathrm{~m} /$ day. The change in RSLE corresponds with change in SCA. Depending on the hypsometric curve of the catchment and duration of the snowmelt event, the mean change in SCA between the start and the peak is for all analysed catchments 17\% (Figure 11). The mean SCA change varies between the countries, but there is no significant statistical relationship with elevation or size of the catchments. The mean changes larger than $25 \%$ are observed in few catchments in France, Sweden and Switzerland. On the other hand smaller changes (i.e. less than 10\%) are observed in some catchments in Slovenia, Austria, Norway and Switzerland.

\section{DISCUSSION AND CONCLUSIONS}

Analysis of snow cover patterns during snowmelt runoff events in Europe indicates that the proportion of snowmelt events increases with increasing elevation and latitude of the catchments and it varies in range from less than $20 \%$ to more than $60 \%$ percent of all runoff events in analysed catchments. The regional snow line elevation during the snowmelt runoff peaks is typically lower than the mean catchment elevation. Most of the snowmelt runoff events start when only a part of the catchment is covered by snow. The most important factors controlling the changes in regional snow line across Europe are latitude and maximum elevation of the catchments. The latitude and elevation control the onset of snowmelt timing and its spatial variability as a surrogate for spatial variability in air temperatures (Clow, 2010). The elevation of the snowline during the start of an event is higher in high altitude catchments and tends to decrease with decreasing altitude of the catchments. In contrary, the change in RSLE between start and peak of a snowmelt event is more related to latitude, i.e. the largest change is observed in southern latitude catchments and the change decreases towards northern latitudes. 
The context and setup of the assessment of MODIS snow line elevation across Europe presented in this study allows evaluating more the spatial than temporal changes. The results show that there are large regional differences, particularly in RSLE change. These differences are likely caused by factors ranging from the large-scale synoptic pattern to land cover and the local energy balance (Mioduszewski et al., 2014), but can also be attributed to uncertainties connected with MODIS snow line estimation. The previously reported limitations of masking effects of cloud (see summary e.g. in Parajka and Blöschl, 2012) limit the estimation of RSLE mainly during the runoff peaks. While the mean cloud coverage during peaks exceeds $81 \%$, the clouds cover on average $60 \%$ of the catchment area during the entire runoff events. The mean event cloud coverage is the largest in Norway, which is consistent with pan-European assessment of MODIS snow cover characteristics presented in Dietz et al. (2012). In their study they reported a tendency of increasing cloud coverage with increasing latitude. The lower cloud coverage around $40^{\circ}$ latitude presented in Dietz et al. (2012) is not detected for snowmelt runoff events in Karasu catchment in Turkey, where the clouds during events exceed on average $60 \%$. Interestingly, in Austria, the mean cloud frequency during entire runoff events is about $10 \%$ lower than the annual mean of $63 \%$ reported in Parajka and Blöschl (2006). This indicates that snow cover and snowline elevation changes can be well captured by MODIS particularly for radiation driven snowmelt runoff events in alpine areas. The other source of uncertainty can be related to the effect of vegetation on the snow cover mapping accuracy, particularly during patchy snow conditions. As the results indicate, most of the analysed snowmelt events were observed during partial snow cover. The previous assessment of Parajka et al. (2012) indicates the mapping accuracy in the forest above $92 \%$, but reports the patchy snow conditions as one of the possible source of misclassification. In the next studies, we therefore plan to investigate the effect of land cover on regional snowline elevation estimation in more detail. We plan to test more extensively the sensitivity and sources of uncertainty (e.g. land cover, terrain slope and topographical shading) on RSLE estimation, as well as to evaluate the spatial coherence and temporal changes of snow line elevation during snowmelt runoff events.

The implications and new research questions are related mainly to the flood regime changes at the continental scale. Merz and Blöschl (2003) suggest classifying floods according to analysis of the climate inputs (rainfall, snowmelt) and the basins state (soil moisture, snow cover). A recent assessment of changes in the seasonality of floods across Europe indicates clear patterns of change in snowmelt flood timing (Blöschl et al., 2017). They report an increase in air temperature that causes an earlier occurrence of spring snowmelt floods particularly throughout north-eastern Europe. Understanding of the underlaying mechanisms and corresponding relations to snow cover changes is indeed important for the prediction of future changes in flood regimes and consequent assessment of changing flood risk across Europe. The spatial patterns in changing snow cover characteristics and snowline elevation across Europe have a large potential for more robust assessment of snowline changes during snowmelt floods and to attribute the trends in past flood changes.

Acknowledgement. This work was supported by the European Commission FP7 funded research projects "Sharing Waterrelated Information to Tackle Changes in the Hydrosphere - for Operational Needs" (grant agreement number 603587), the European Research Council under the ERC Advanced Grant
"Flood Change", project no. 291152) and the Slovenian Research Agency (grant P2-0180). The financial support is gratefully acknowledged. We would like also to thank the Global Runoff Data Centre, Koblenz, Germany and Czech Hydrometeorological Institute for providing daily runoff data for this work.

\section{REFERENCES}

Blöschl, G., Hall, J., Parajka, J., Perdigão, R.A.P., Merz, B., Arheimer, B., Aronica, G.T., Bilibashi, A., Bonacci, O., Borga, M., Čanjevac, I., Castellarin, A., Chirico, G.B., Claps, P., Fiala, K., Frolova, N., Gorbachova, L., Gül, A., Hannaford, J., Harrigan, S., Kireeva, M., Kiss, A., Kjeldsen, T.R., Kohnová, S., Koskela, J.J., Ledvinka, O., Macdonald, N., Mavrova-Guirguinova, M., Mediero, L., Merz, R., Molnar, P., Montanari, A., Murphy, C., Osuch, M., Ovcharuk, V., Radevski, I., Rogger, M., Salinas, J.L., Sauquet, E., Šraj, M., Szolgay, J., Viglione, A., Volpi, E., Wilson, D., Zaimi, K., Živković, N., 2017. Changing climate shifts timing of European floods. Science, 357, 6351, 588-590. DOI: 10.1126/science.aan2506.

Ceola, S., Arheimer, B., Baratti, E., Blöschl, G., Capell, R., Castellarin, A., Freer, J., Han, D., Hrachowitz, M., Hundecha, Y., Hutton, C., Lindström, G., Montanari, A., Nijzink, R., Parajka, J., Toth, E., Viglione, A., Wagener, T., 2015. Virtual laboratories: new opportunities for collaborative water science. Hydrol. Earth Syst. Sci., 19, 2101-2117. DOI: 10.5194/hess-19-2101-2015.

Chapman, T., 1999. A comparison of algorithms for stream flow recession and baseflow separation. Hydrological Processes, 13, 5, 701-714.

Clow, D.W., 2010. Changes in the timing of snowmelt and streamflow in Colorado: A response to recent warming. Journal of Climate, 23, 2293-2306. https://doi.org/10.1175/2009JCLI2951.1.

Collins, D.N., 1998. Rainfall-induced high-magnitude runoff events in highly-glacierized Alpine basins. In: Proceedings of the HeadWater'98 Conference on Hydrology, Water Resources and Ecology in Headwaters (Meran/Merano, Italy, April 1998). IAHS Publ. no. 248, pp. 69-78.

Déry, S.J., Salomonson, V.V., Stieglitz, M., Hall, D.K., Appel, I., 2005. An approach to using snow areal depletion curves inferred from MODIS and its application to land surface modelling in Alaska. Hydrological Processes, 19, 27552774. DOI: 10.1002/hyp.5784.

Dietz, A.J., Wohner, Ch., Kuenzer, C., 2012. European snow cover characteristics between 2000 and 2011 derived from improved MODIS daily snow cover products. Remote Sensing, 4, 8, 2432-2454. DOI: 10.3390/rs4082432.

Gascoin, S., Hagolle, O., Huc, M., Jarlan, L., Dejoux, J.-F., Szczypta, C., Marti, R., Sánchez, R., 2015. A snow cover climatology for the Pyrenees from MODIS snow products. Hydrol. Earth Syst. Sci., 19, 2337-2351.

Hall, D.K., Riggs, G.A., 2016. MODIS/Terra Snow Cover Daily L3 Global 500m Grid, Version 6. [Indicate subset used]. Boulder, Colorado USA. NASA National Snow and Ice Data Center Distributed Active Archive Center. DOI: http://dx.doi.org/10.5067/MODIS/MOD10A1.006. [Date Accessed].

Krajčí, P., Holko, L., Perdigão, R.A.P., Parajka, J., 2014. Estimation of regional snowline elevation (RSLE) from MODIS images for seasonally snow covered mountain basins. Journal of Hydrology, 519, 1769-1778. 
Li, B., Zhu, A.-X., Zhou, C., Zhang, Y., Pei, T., Qin, C., 2008. Automatic mapping of snow cover depletion curves using optical remote sensing data under conditions of frequent cloud cover and temporary snow. Hydrol. Process., 22, 2930-2942. DOI: 10.1002/hyp.6891.

Mangini, W., Viglione, A., Hall, J., Hundecha, Y., Ceola, S., Montanari, A., Rogger, M., Salinas, J.L., Borzì, I., Parajka, J., 2018. Detection of trends in magnitude and frequency of flood peaks across Europe, Hydrological Science Journal, https://doi.org/10.1080/02626667.2018.1444766. (In press).

Merz, R., Blöschl, G., 2003. A process typology of regional floods. Water Resources Research, 39, 12, 39, 1340. DOI: 10.1029/2002WR001952, 12.

Mioduszewski, J.R., Rennermalm, A.K., Robinson, D.A., Mote, T.L., 2014. Attribution of snowmelt onset in Northern Canada. J. Geophys. Res. Atmos., 119, 9638-9653. DOI: 10.1002/ 2013JD021024.

Parajka, J., 2017. Catalogue of identified flood peaks from GRDC dataset (FLOOD TYPE experiment). DOI: 10.5281/zenodo.581436.

Parajka, J., Blöschl, G., 2006. Validation of MODIS snow cover images over Austria. Hydrology and Earth System Sciences, 10, 679-689.

Parajka, J., Blöschl, G., 2012. MODIS-based snow cover products, validation, and hydrologic applications. In: Chang, N.B., Hong, Y. (Eds.): Multiscale Hydrologic Remote Sensing: Perspectives and Applications. CRC Press, Taylor \& Francis Group, Boca Raton, Florida, USA, pp. 185-212.

Parajka, J., Holko, L., Kostka, Z., Blöschl, G., 2012. MODIS snow cover mapping accuracy in a small mountain catchment - comparison between open and forest sites. Hydrology and Earth System Sciences, 16, 2365-2377.
Paudel, K.P., Andersen, P., 2011. Monitoring snow cover variability in an agropastoral area in the Trans Himalayan region of Nepal using MODIS data with improved cloud removal methodology. Remote Sens. Environ., 115, 5, 1234-1246.

Riboust, P., Thirel, G., Le Moine, N., Ribstein, P., 2019. Revisiting a simple degree-day model for integrating satellite data: implementation of SWE-SCA hystereses. Journal of Hydrology and Hydromechanics, 67, 70-81.

Thomas, B.F., Vogel, R.M., Kroll, C.N., Famiglietti, J.S., 2013. Estimation of the base flow recession constant under human interference. Water Resources Research, 49, 7366-7379. DOI: $10.1002 /$ wrcr.20532.

Vogel, R.M., Kroll, C.N., 1996. Estimation of baseflow recession constants. Water Resources Management, 10, 303-320.

Wang, X., Xie, H., Liang, T., Huang, X., 2009. Comparison and validation of MODIS standard and new combination of Terra and Aqua snow cover products in northern Xinjiang, China. Hydrol. Process., 23, 3, 419-429.

Wang, W., Huang, X., Deng, J., Xie, H., Liang, T., 2015. Spatio-temporal change of snow cover and its response to climate over the Tibetan plateau based on an improved daily cloud-free snow cover product. Remote Sens., 7, 1, 169194.

Xinghua, L, Wenxuan, F., Huanfeng, S., Chunlin, H., Liangpei, Z., 2017. Monitoring snow cover variability (2000-2014) in the Hengduan Mountains based on cloud-removed MODIS products with an adaptive spatio-temporal weighted method. Journal of Hydrology, 551, 314-327.

Received 28 September 2017 Accepted 19 February 2018 